\title{
ANALISIS KUALITATIF IMPLEMENTASI FOUR EYES PRINCIPLES BANK SYARIAH ( Study Kasus Sharia Business Unit BTN Syariah )
}

\author{
Edy Junaedi ${ }^{1}$ \\ edyjunaedi.sayuti@gmail.com
}

\begin{abstract}
Purpose the present paper explores the application of the four eyes priciples to management decision in banking sector, a heretofore neglected area of business and management research. Methodology approach a theoritical analysis was first conducted of the four eyes principles. A qualitative field study of sharia business unit of Bank BTN. Non Performance Financing based on type shari'ah compliant contract of sharia business units and sharia commercial banks have shown that negative growth until 2017, four eyes principles is a model to make decision togather in financing. The requirement that a business transaction be approved by at least two individual who must both sign off on any significant financing decision

Findings: from theoretical analysis, it can be conclude that the four eyes principles may generally conducted serve as a mechanism to mitigate risk of financing. Due to a non performing financing

Keywords : four eyes principles, mitigate risk, non performing financing
\end{abstract}

\section{Pendahuluan}

Bisnis perbankan syariah secara bertahap terus membukukan pertumbuhan yang cukup berarti. Namun, seperti bisnis perbankan konvensional, bisnis perbankan syariah juga tidak terlepas dari persoalan pembiayaan bermasalah. Perkembangan kredit bermasalah bank syariah selama decade terakhir relatif merangak naik sebagaimana data dari Sharia Banking Statistic sebagai berikut :

\section{Tabel 1}

Perkembangan Kredit Macet Bank Syariah

\begin{tabular}{|c|c|c|c|c|r|r|r|r|r|r|}
\hline $\begin{array}{c}\text { Bank } \\
\text { Syariah }\end{array}$ & 2008 & 2009 & 2010 & 2011 & 2012 & 2013 & 2014 & 2015 & 2016 & 2017 \\
\hline BUS \&UUS & 3.95 & 4 & 3 & 2 & 2 & 2 & 4 & 4 & 4 & \\
\hline BPRS & 8.38 & 7.03 & 6.51 & 6.11 & 6.15 & 6.50 & 7.89 & 8.20 & 8.63 & 9.68 \\
\hline
\end{tabular}

Sumber : Otoritas Jasa Keuangan- Sharia Banking Statistic

\footnotetext{
${ }^{1}$ Dosen Tetap Prodi Perbankan Syariah STAI Asy-Syukriyyah
} 


\section{Jurnal Asy-Syukriyyah}

Pada tahun 2014 kredit macet tumbuh signifikan rata-rata peningkatan nominal kredit macet naik di atas 1 persen, Bank Umum Syariah dan Unit Usaha Syariah dari 2,62 persen tahun 2013 menjadi 4.33 persen pada tahun 2014 dan BPRS dari 6.50 persen pada tahun 2013 menjadi 7.89 persen pada tahun 2014, secara industry pembiayaan macet sampai dengan tahun 2017 makin tinggi hingga 4.77 di tahun 2017 untuk BUS dan UUS, sementara BPRS lebih mengkawatirkan mencapai 9.68 persen di tahun 2017. Hal tersebut menjadikan bank syariah melakukan evaluasi kebijakan pembiayaan salah satunya melalui penerapan four eyes principles dalam memutus perkreditan.

BTN Syariah merupakan Unit Usaha Syariah (UUS) dari Bank BTN (Persero).Tbk yang menjalankan bisnis dengan prinsip Syariah. BTN Syariah mulai beroperasi pada tanggal 14 Februari 2005 melalui pembukaan Kantor Cabang Syariah pertama di Jakarta Harmoni,dan sampai dengan Juni 2016 telah dibuka 23 Kantor Cabang, 1 Kantor Cabang Pembantu Syariah, dengan 119 Kantor Layanan Syariah. Tujuan dari pendirian UUS Bank BTN adalah untuk memenuhi kebutuhan nasabah akan produk dan layanan perbankan yang sesuai dengan prinsip Syariah dan memberi manfaat yang setara, seimbang dalam pemenuhan kepentingan bersama antara nasabah dan Bank.

Sebagai bagian dari Bank BTN yang merupakan Bank BUMN, BTN Syariah menjalankan fungsi intermediasi dengan menghimpun dana masyarakat melalui produkproduk Giro, Tabungan, dan Deposito, dan menyalurkan kembali ke sektor riil melalui berbagai produk pembiayaan KPR, Multiguna, Investasi dan Modal Kerja.

Sesuai dengan motonya : "Maju dan Sejahtera Bersama" maka BTN Syariah mengutamakan prinsip keadilan dan kesetaraan dalam penerapan imbal hasil antara nasabah dan Bank. Sebagai lembaga intermediary dan seiring dengan situasi lingkungan eksternal dan internal perbankan mengalami perkembangan pesat, bank syariah akan selalu berhadapan dengan berbagai jenis risiko dengan tingkat kompleksitas yang beragam dan melekat pada kegiatan usahanya. Risiko dalam konteks perbankan merupakan suatu kejadian potensial, baik yang dapat diperkirakan (anticipated) maupun yang tidak dapat diperkirakan (unanticipated) yang berdampak negative terhadap pendapatan dan permodalan bank. Risiko-risiko tersebut tidak bisa dihindari, tetapi dapat dikelola dan dikendalikan. Oleh karena itu sebagai lembaga perbankan pada umumnya, bank syariah juga memerlukan serangkaian prosedur dan metodologi yang dapat digunakan untuk mengidentifikasi, mengukur, memantau, dan mengendalikan risiko yang timbul dari kegiatan usaha, atau yang biasa disebut sebagai manajemen risiko. 


\section{Jurnal Asy-Syukriyyah}

Pembiayaan merupakan aktivitas yang sangat penting bagi Bank Islam karena dengan pembiayaan akan diperoleh sumber pendapatan utama dan menjadi penunjang kelangsungan usaha Bank Islam baik Bank Umum Syariah, Unit Usaha Syariah maupun Bank Pembiayaan Rakyat Syariah. Sebaliknya bila pegelolaannya tidak baik akan menimbulkan permasalahan dan berhentinya usaha Bank. Penerapan manajemen risiko kredit/pembiayaan ini dimaksudkan untuk menilai risiko kredit/pembiayaan yang melekat pada pelaksanaan pemberian kredit/pembiayaan. Hal yang penting didalam penerapan manajemen risiko kredit/pembiayaan adalah adanya prosedur dan metodologi pengelolaan risiko kredit/pembiayaan sehingga kegiatan usaha bank dalam hal ini kredit/pembiayaan dapat terkendali pada batas yang dapat diterima. Manajemen risiko kredit/pembiayaan diterapkan sebagai upaya meningkatkan efektivitas prudential banking. Situasi lingkungan eksternal dan internal perbankan mengalami perkembangan pesat yang diikuti dengan semakin kompleksnya risiko kegiatan usaha perbankan sehingga meningkatkan kebutuhan praktek tata kelola bank yang sehat (good cooperate governance) dan penerapan manajemen risiko yang meliputi pengawasan aktif pengurus bank, kebijakan, prosedur dan penetapan limit risiko, proses identifikasi, pengukuran, pemantauan, sistem inFourmasi, dan pengendalian risiko serta sistem pengendalian intern.

Dengan semakin kompleksnya risiko kegiatan usaha perbankan, maka Perbankan Islam (Perbankan Syariah) dituntut untuk menerapkan prinsip kehati-hatian (Prudential Banking) dan Good Coorporate Governance (GCG). Guna mewujudkan visi dan misi dan mengantisipasi kompleksitas risiko kegiatan usaha perbankan, khususnya dalam bidang pembiayaan, maka dipandang perlu untuk melakukan penyempurnaan dalam proses bisnis dan pengambilan keputusan kredit/pembiayaan komersial yang dilakukan melalui Four Eyes Principle (PEF). (SE BI NO. 13/23/DPNP tanggal 25 Oktober 2011 perihal penerapan manajemen Resiko Bagi Bank Umum (hal 25) "Bank Wajib melaksanakan system pengendalian intern secara efektif dalam penerapan manajemen resiko Bank dengan mengacu pada kebijakan dan prosedur yang telah ditetapkan.Penerapan prinsip pemisahan fungsi (Four eyes principle) harus memadai dan dilaksanakan dengan penuh tanggung jawab".

Four Eyes Principle merupakan sebuah prinsip dimana keputusan kredit/pembiayaan harus melibatkan sinergi antara bisnis unit yang bertanggung jawab 
dalam pencapaian pendapatan dan unit risiko kredit/pembiayaan yang bertanggung jawab dalam meminimalisir biaya risiko kredit/pembiayaan.

Four Eyes Principle merupakan prinsip utama yang mendasari pengambilan keputusan dalam pemberian kredit/pembiayaan dimana setiap pemberian kredit/pembiayaan minimal dilakukan oleh 2 (dua) orang pejabat yang masing-masing berasal dari unit bisnis dan unit resiko kredit/pembiayaan yang saling independen satu sama lain.

Latar Belakang pelaksanaan Four Eye Principle pada Bank Tabungan Negara (Persero) dan UUSnya dimulai dari hasil self Assesment Otoritas Jasa Keuangan (OJK) mengenai Tingkat Kesehatan Bank (TKB) tahun 2014 dimana variable yang dinilai adalah Profil Resiko,GCG,Rentabilitas, dan Permodalan dengan katagori penilaian (PBI No, 13/1/PBI/2011 tanggal 05/10/2011dan SEBI No.13/24/DPNP tanggal 25/10/2011Tentang Penilaian Tingkat kesehatan Bank Umum sbb :

1. PK 1 Sangat sehat

2. PK 2 Sehat

3. PK 3 Cukup Sehat

4. $\quad$ PK 4 Kurang sehat

5. $\quad$ PK 5 Tidak sehat

Didapat kesimpulan bahwa Bank BTN mendapat penilaian PK 4 Kurang Sehat yang mengakibatkan Inhern Risk tinggi dan KPMR tidak memadai dengan konsekuensi negatif terhadap bisnis diantaranya :

- $\quad$ Credit rating Obligasi yang diterbitkan dapat memburuk

- $\quad$ Coupon Rate obligasi menjadi tinggi

- $\quad$ Pemilik Dana meminta Rate yang tinggi

- $\quad$ Kesempatan mendapat dana reboisasi menjadi hilang (Min PK2)

- Tidak diizinkan mendirikan perusahaan anak, Kantor Wilayah,Kantor Cabang, Kancapem dan/atau Kankas

Berdasarkan hasil temuan OJK tersebut dan mengacu kepada PBI No.11/25/PBI/2009 tanggal 1 Juli 2009 tentang Perubahan atas Peraturan Bank Indonesia Nomor 5/8/PBI/2003 tentang Penerapan manajemen Risiko Bagi Bank Umum, maka dipandang perlu BTN mengatur adanya pemisahan fungsi antara unit kerja pengambil keputusan kredit dengan unit kerja pembuat kebijakan. Dalam perkembangannya, Risk Management Division, memandang perlu untuk membentuk suatu unit kerja Risk 


\section{Management yang turut terlibat operasional pada bidang kredit sebagai unit yang melengkapi fungsi four eyes principles dalam pengambilan keputusan kredit.}

Hal tersebut Ditindaklanjuti dengan pembentukan Tim Penyusunan Implementasi Four Eyes Principles di Bank BTN (. khususnya pembentukan unit Risk Analys dan penyesuaian proses bisnis) dengan time line rencana kerja.

Secara besaran rencana kerja dimaksud dengan schedule sebagai berikut : Ijin Prinsip Direksi Proses Penunjukan Konsultan Proses Penyusunan (Blue Print) Persetujuan Direksi Persiapan Implementasi Go Live Jan 2015.

Berdasarkan time line tersebut maka dilakukan workshop untuk menyusun bisnis proses implementasi Four eyes principles dengan melibatkan perwakilan/narasumber dari divisi terkait, kantor wilayah dan kantor cabang dengan difasilitasi konsultan eksternal, kemudian sebelum adanya implementasi penerapan Four Eyes Principle mekanisme pengambilan keputusan pembiayaan Komersial Bank BTN induk maupun UUSnya dilakukan hanya oleh pengusul kredit/pembiayaan dalam hal ini Analys dan Pejabat Unit Bisnis (analys Komersial ,Deputy Branch Manager Bisnis ) kemudian diusulkan kepada pemutus Kredit/Pembiayaan (Branch Manager) tidak melibatkan unit manapun, akan tetapi sejak Januari 2015 maka mekanisme pengambilan keputusan Kredit/Pembiayaan komersial selain dari Pengusul (Analys dan Pejabat Unit Bisnis Cabang ) sebelum diputuskan maka wajib melibatkan Branch Credit Risk Head (BCRH) dari unit Credit Risk Desk (CRD) sebelum diusulkan kepada Branch Manager sebagai pemutus berdasarkan SE No. 15//DIR/CRD/2016.

Alur Proses Pengambilan Keputusan pembiayaan Komersial sebelum dan sesudah Penerapan Four Eyes Principle:

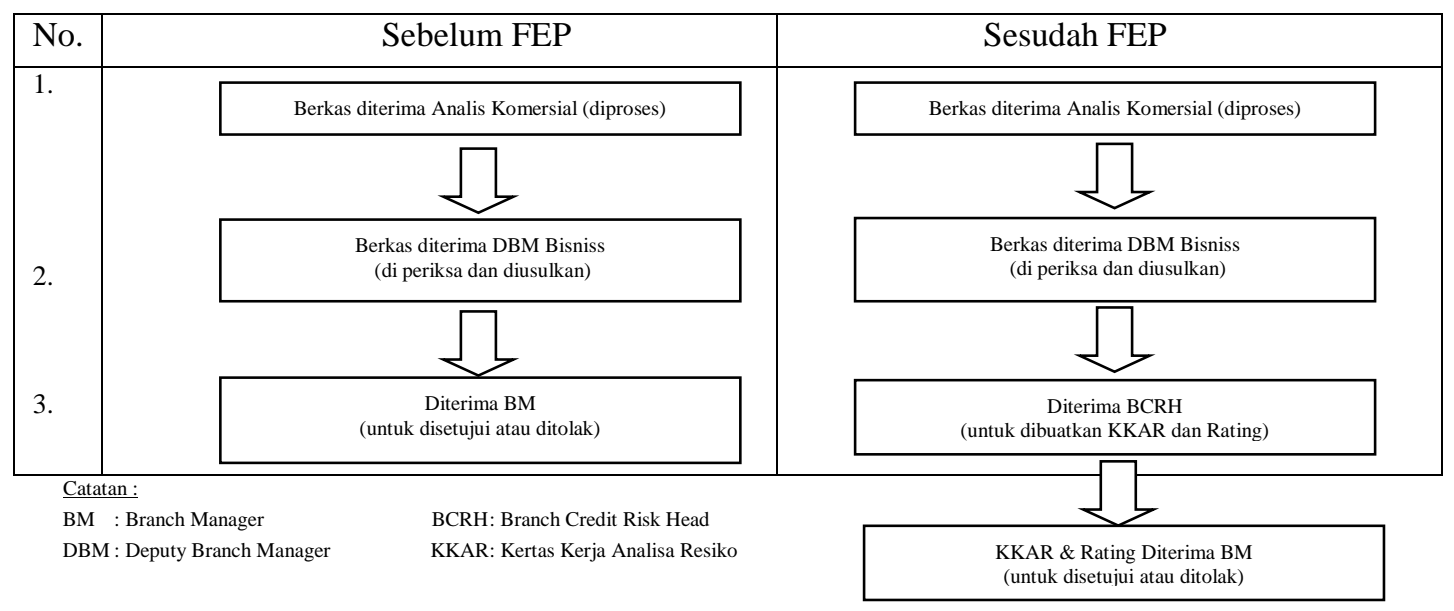




\section{Jurnal Asy-Syukriyyah}

Alur mekanisme putusan Pembiayaan komersial setelah terbitnya SE No.15 /DIR/CRD/2016 berkas diproses oleh Analis komersial kemudian diserahkan kepada DBM Bisnis untuk direview kemudian usulan pembiayaan tersebut diserahkan kepada BCRH untuk dibuatkan Kertas kerja analisa resiko dan Rating Pembiayaan kemudian BCRH menyerahkan Branch Manager untuk disetujui atau ditolak, Apabila dari hasil Analisa Resiko BCRH disetujui maka BM berhak menolak, akan tetapi sebaliknya apabila berdasarkan KKAR BCRH menolak maka BM tidak bisa menyetujui, jika BM menganngap pembiayaan tersebut layak disetujui maka BM harus membuat surat usulan kepada pemutus yang lebih tinggi kewenangannya yaitu Regional Officer (RO), dengan resiko bertanggung jawab penuh dikemudian hari apabila pembiayaan yang sdh tidak direkomendasikan BCRH terjadi NFP dan lain lain sebagainya yang berkenaan dengan debitur pembiayaan melakukan wan prestasi.

Bank memperoleh pendapatan melalui pemberian/penyaluran kredit/pembiayaan atau pembiayaan kepada masyarakat. Menurut UU Perbankan No. 10 Tahun 1998 tentang perubahan UU No. 7 Tahun 1992 tentang Perbankan, pengertian Kredit adalah "Penyediaan uang atau tagihan yang dapat dipersamakan dengan itu, berdasarkan persetujuan atau kesepakatan pinjam memimjam antara bank dengan pihak lain yang mewajibkan pihak meminjam untuk melunasi utangnya setelah jangka waktu tertentu dengan pemberian keuntungan berupa bunga". Sedangkan pengertian Pembiayaan dalam Pasal 1(12) adalah "Penyedian uang atau tagihan yang dapat dipersamakan dengan itu, berdasarkan persetujuan atau kesepakatan antar bank dengan pihak lain yang mewajibkan pihak yang dibiayai untuk mengembalikan uang atau tagihan tersebut setelah jangka waktu tertentu dengan imbalan atau bagi hasil".

Semakin tinggi permintaan kredit/pembiayaan yang dapat dipenuhi oleh bank maka kemungkinan memperoleh laba usaha juga akan semakin meningkat. Namun dalam pemberian kredit/pembiayaan pada masyarakat bank harus menggunakan prinsip kehatihatian karena jika tidak dilakukan, maka bank akan terancam dalam masalah kredit/pembiayaan macet dan akan mengalami kerugian. Sehingga akan berdampak pada tingkat kepercayaan masyarakat yang menitipkan dana simpanannya sebagai sumber dana usaha bank.

Kredit/pembiayaan bermasalah akan muncul apabila debitur tidak dapat memenuhi kewajibannya. Didalam pemberian kredit/pembiayaan/ akan ada kemungkinan 


\section{Jurnal Asy-Syukriyyah}

tidak tercapainya kesepakatan yang telah disepakati oleh debitur dan bank. Inilah yang sering disebut sebagai risiko kredit/pembiayaan dan risiko kredit/pembiayaan ini berbentuk kredit/pembiayaan bermasalah. Yang tergolong kredit/pembiayaan bermasalah didalam keseluruhan kriteria kredit/pembiayaan adalah kredit/pembiayaan Dalam Perhatian Khusus (DPK), Kurang Lancar (KL), Diragukan dan Macet (DRM).

Perbankan yang dapat menjaga sustainabilitasnya dalam menjalankan usaha adalah perbankan yang dapat menerapkan manajemen risiko dengan baik. Manajemen risiko perbankan menjadi mutlak untuk mengendalikan risiko khususnya dalam bidang perkredit/pembiayaanan dimana setiap pejabat/petugas kredit/pembiayaan harus menjalankan prinsip kehati-hatian (prudential principles) guna memitigasi risiko.

Manajemen resiko adalah suatu pendekatan terstruktur/metodologi dalam mengelola ketidakpastian yang berkaitan dengan ancaman; suatu rangkaian aktivitas manusia termasuk: Penilaian risiko, pengembangan strategi untuk mengelolanya dan mitigasi risiko dengan menggunakan PBI No,5/8/PBI/2003 tentang penerapan manajemen resiko bagi bank umum disebutkan Manajemen Resiko adalah serangkaian prosedur dan metodologi yang digunakan untuk mengidentifikasi, mengukur, memantau, dan mengendalikan Risiko yang timbul dari kegiatan usaha Bank

Four Eyes Principle merupakan sebuah prinsip dimana keputusan kredit/pembiayaan harus melibatkan sinergi antara bisnis unit yang bertanggung jawab dalam pencapaian pendapatan dan unit risiko kredit/pembiayaan yang bertanggung jawab dalam meminimalisir biaya risiko kredit/pembiayaan.

Four Eyes Principle merupakan prinsip utama yang mendasari pengambilan keputusan dalam pemberian kredit/pembiayaan dimana setiap pemberian kredit/pembiayaan minimal dilakukan oleh 2 (dua) orang pejabat yang masing-masing berasal dari unit bisnis dan unit resiko kredit/pembiayaan yang saling independen satu sama lain.

Pelaksanaan bisnis perbankan terutama UUS Bank BTN yang berbasis pada manajemen risiko dewasa ini bukan saja hanya melalui pemberian opini risiko, namun sudah jauh berkembang diantaranya dengan pelaksanaan Four Eyes Principle dalam pengambilan keputusan kredit/pembiayaan komersial. Dengan penerapan Four Eyes Principle ini diharapkan dapat meningkatkan kualitas pemberian Kredit Komersial agar pelaksanaanya berjalan sesuai dengan ketentuan dan regulasi (compliance), sehingga dapat 
meminimalisir risiko pembiayaan dan risiko lainnya yang dapat menimbulkan kerugian Bank.

Permasalahan dalam penelitian ini adalah Bagaimanakah arah Bank Syariah menurut Al-Qur'an dalam memitigasi dan mengantisipasi kredit macet (Non Performing Financing) dan bagaimanakah teknis kebijakan Bank Syariah dalam memitigasi dan mengantisipasi kredit macet (Non Performing Financing).

\section{Kajian Teori}

Islam merupakan agama fitrah yang komplit dan menyeluruh. Oleh karena itu tidak ada satu pun urusan fitrah yang luput dari perhatian syariat islam. Tidak ada sesuatu pun, dalam urusan dunia maupun akhirat, kecuali islam telah menjelaskan perkaranya. Allah ta'ala berfirman dalam surat al-An'am ayat 38 yang artinya :

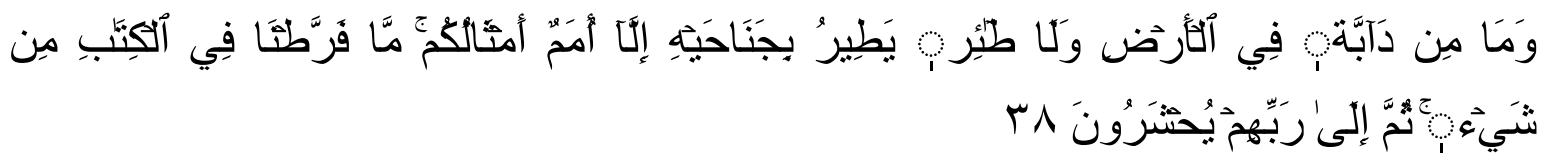

"dan tiadalah binatang-binatang yang ada dibumi dan burung - burung yang terbang dengan kedua sayapnya, melainkan umat juga sepertimu. Tiadalah kami alpakan sesuatupun dalam al-kitab (Al-qur'an), kemudian kepada tuhanlah mereka dihimpunkan”.

Ayat tersebut dijelaskan lebih lanjut dalam hadis nabi dari Abu dzar Al-ghifary radhiyallahu' anhu, ia berkata : Rasulullah shalallahu 'alahi wa sallam telah pergi meninggalkan kami (wafat), dan tidaklah seekor burung yang terbang membolak-balikan kedua sayapnya di udara melainkan beliau telah menerangkan ilmunya kepada kami. Berkata Abu Dzar radhiyallahu'anhu: Rasulullah shalallahu'alahi wa salam telah bersabda : tidaklah tertinggal sesuatu pun yang mendekatkan ke surga dan menjauhkan dari neraka melainkan telah dijelaskan semuanya kepada kalian. “ ( HR. Ath-Thabrani dan Ibnu Hibban).

Dari ayat dan hadis diatas bahwa islam adalah din dan syariat yang mengatur hubungan manusia dengan allah Ta'ala, hubungan manusia dengan pribadinya sendiri,keluarga, dan sesama manusia dalam bentuk muamalah (sosial) demi kemaslahatan hidup mereka. Oleh karena itu, islam merupakan agama yang lengkap dan sempurna 


\section{Jurnal Asy-Syukriyyah}

mengatur 3 yang artinya: "pada hari ini telah ku-sempurnakan untukmu agama, dan telah kucukupkan nikmat-ku atasmu, dan telah kuridhai islam itu jadi agama bagimu”.

\section{Kebijakan Mitigasi Risiko}

Dalam usahanya mencari nafkah, seorang muslim dihadapkan pada kondisi ketidakpastian terhadap apa yang terjadi. Kita boleh saja merencanakan suatu kegiatan usaha atau investasi, namun kita tidak bisa memastikan apa yang akan kita dapatkan dari hasil investasi tersebut, apakah untung atau rugi. Hal ini merupakan sunnatullah atau ketentuan Allah seperti yang disampaikan kepada Nabi Muhammad saw, 1400an tahun yang silam dalam Surat Luqman ayat 34 berikut:

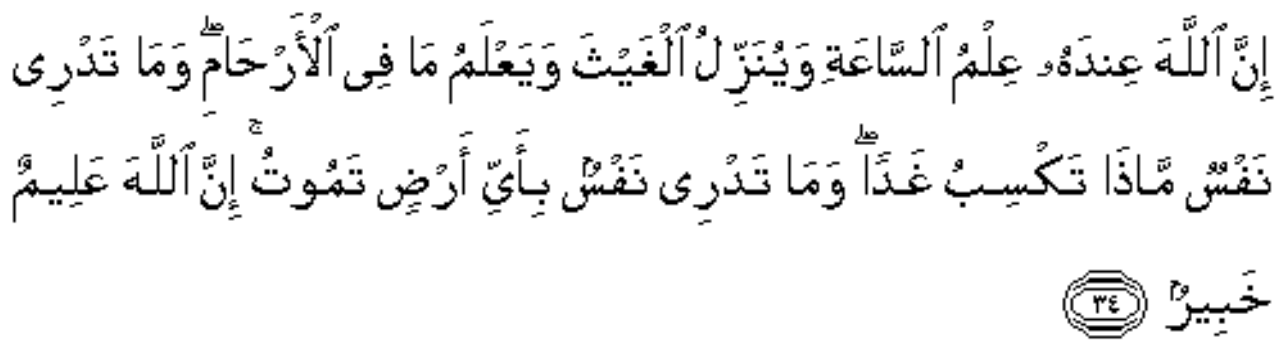

"dan tidak seorangpun yang dapat mengetahui dengan pasti apa-apa yang diusahakannya esok.." [QS Luqman: 34]

Ayat tersebut menjadi dasar pemikiran konsep risiko dalam Islam, khususnya kegiatan usaha dan investasi. Selanjutnya dalam surat Al Hasyr ayat 18, Allah berfirman:

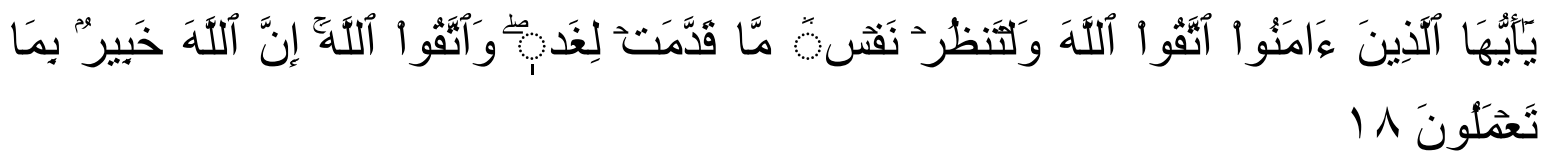

"Hai orang yang beriman, bertakwalah kamu kepada Allah dan hendaklah setiap diri memperhatikan apa yang telah diperbuatnya untuk hari esok, dan bertakwalah kepada Allah, sesungguhnya Allah Maha Mengetahui apa yang kamu kerjakan." [QS. Al Hasyr : 18]

Konsep ketidakpastian dalam ekonomi islam menjadi salah satu pilar penting dalam proses manajemen risiko islami. Secara natural, dalam kegiatan usaha, di dunia ini tidak ada seorangpun yang menginginkan usaha atau investasinya mengalami kerugian. Bahkan dalam tingkat makro, sebuah negara juga mengharapkan neraca perdagangannya 
yang positif. Kaidah syariah tentang imbal hasil dan risiko adalah $\mathrm{Al}$ ghunmu bil ghurmi, artinya risiko akan selalu menyertai setiap ekspektasi return atau imbal hasil.

Kegiatan perniagaan (bisnis) merupakan salah satu fitrah dari manusia karena dengan berniaga manusia dapat memenuhi berbagai keperluannya. Setiap bisnis yang dijalankan oleh manusia pasti akan menimbulkan dua konsekuensi dimasa depan, yaitu keuntungan dan kerugian. Keduanya merupakan dua hal yang tidak terpisahkan dari kegiatan bisnis. Tidak ada satu pun yang bisa menjamin bahwa bisnis yang dijalankan oleh seseorang akan mengalami keuntungan atau kerugian dimasa depan. Dengan demikian, resiko itu sendiri merupakan fitrah yang senantiasa melekat dalam kehidupan manusia. Oleh karenanya, islam tidak mengenal adanya transaksi bisnis yang bebas resiko.

Para ulama telah bersepakat bahwa terdapat dua kaidah penting yang harus diperhatikan dalam menjalankan bisnis dan setiap transaksi usaha, yaitu kaidah al-kharaj bidh dhaman (pendapatan adalah imbalan atas tanggungan yang diambil) dan al ghunmu bil ghurmi (keuntungan adalah imbalan atas kesiapan menanggung kerugian). Kedua kaidah tersebut bersumber dari hadis nabi shalalahu 'alaihi wa sallam: "dari aisyah radhiyallahu anha bahwasannya seseorang lelaki membeli seorang budak laki-laki. Kemudian budak tersebut tinggal bersamanya selama beberapa waktu. Suatu hari sang pembeli mendapakan adanya cacat pada budak tersebut. Kemudian pembeli mengadukan penjual kepada nabi shalallahu 'alaihi wa sallam dan nabi pun memutuskan agar budak tersebut dikembalikan. Maka penjual berkata "ya rasulullah! Sungguh ia telah memperkerjakan budakku? ". Maka rasulullah bersabda: "keuntungan adalah imbalan atas kerugian. "(HR. Ahmad, At-Tirmidzi, Abu dawud, An-Nasai dan dihasankan oleh Al-Bani).

Maksud dari kedua kaidah tersebut di atas adalah orang yang berhak mendapatkan keuntungan ialah orang yang punya kewajiban menanggung kerugian (jika hal itu terjadi). Keuntungan merupakan kompensasi yang pantas atas kesediaan seseorang menanggung potensi kerugian. Seorang pedagang berhak mengambil keuntungan atas kesedian seseorang menanggung potensi kerugian. Seorang pedagang berhak mengambil keuntungan atas barang yang dijualnya karena ia telah menanggung seluruh resiko terkait barang dagangnya (kerusakan barang sebelum terjual, kehilangan barang dagang, tidak laku, dan lain sebagainya). Seorang mudharib dan shahibul maal dalam transaksi mudharabah masing-masing berhak atas pembagian keuntungan usaha karena setiap pihak menanggung resiko kehilangan modal dan mudharib menanggung risiko, maka keduanya pun berhak atas bagian keuntungan usaha. Dengan kedua kaidah tersebut, islam 
menghilangkan ketidakadilan dan melindungi hak setiap pihak yang terlibat dalam transaksi bisnis.

Konsekuensi logis lainnya dari kaidah "al-kharaju bidh dhamani" dan "al-ghunmu bil ghurmi" adalah islam melarang setiap jenis transaksi yang didalamnya terjadi ketidakseimbangan antar risiko dan keuntungan. Dengan kata lain, islam melarang setiap jenis transaksi yang menghasilkan keuntungan. Dengan kata lain islam melarang setiap jenis transaksi yang menghasilkan keuntungan tanpa adanya kesediaan menanggung kerugian. Itulah mengapa islam melarang adanya tambahan (bunga) dalam transaksi utang seperti biasa terjadi dalam sistem keuangan konvesional. Pemberi pinjaman tidak memiliki resiko apa pun atas dana yang dipinjamkannya karena islam mewajibkan setiap pinjaman untuk melunasi utangnya. Oleh karena itu setiap tamabahan atas pengembalian utang dianggap sebagai riba. Jika tambahan atas untang diperbolehkan, maka ketidak adilan akan terjadi dimana -mana. Seorang pemberi pinjaman tanpa melakukan usaha dapat memperoleh keuntungan yang besar sementar si peminjam harus bersusah payah untuk melunasi utang beserta bunganya kepada pemilik dana. Inilah yang berutang tidak akan pernah bisa bangkit dari kemiskinan karena terus dililit oleh besarnya bunga utang sementara si kaya akan makin kaya kerana uangnya dapat berlipat ganda tanpa harus bersusah payah menjalankan usaha.

Risiko berdasarkan pengertian tradisional berarti kemungkinan menemui kegagalan, kehilangan dan bahaya. Risiko adalah elemen kehidupan di dunia ini. Ini juga salah satu faktor investasi dimana seseorang harus mengambil waktu unuk mengerti mengenai penyeleksian instrumen investasi yang spesifik dari petualangan yang baru. Banyak kaum muslim menyalah artikan konsep tersebut. Beberapa muslim percaya bahwa masa akan dating adalah berada pada tangan Tuhan sehingga tidak perlu berusaha untuk menggapainya padahal seharusnya seorang muslim bekerja keras untuk memenuhi kondisi tersebut.

Sejarah mengenai nabi juga merupakan pelajaran yang sangat berarti mengenai bagaimana seorang muslim harus mengelola risiko. Pada perencanaan keuangan Islam, takaful adalah cara untuk mengurangi risiko hilangnya keuangan akibat sebuah hal yang tidak sengaja dilakukan atau ketidakberuntungan. Takaful secara literak berarti jaminan saling menguntungkan dan solidaritas. Hal ini telah didefinisikan pada takaful act 1984 sebagai skema berdasarkan saling menguntungkan, yang mana menyediakan tujuan keuangan yang saling menguntungkan dan membantu para peserta sebagai kasus 
membutuhkan dimana para peserta setuju untuk berkontribusi pada tujuan.Transaksi keuangan ini adalah hubungan yang saling menguntungkan diantara kedua belah pihak untuk melindungi dari risiko yang tidak diekspektasikan dimasa datang.

Sebagai sebuah fakta, perencanaan takaful adalah perencanaan pembagian risiko dimana shahibul maal dan mudharib sama-sama menanggung kerugian. Pada perencanaan takaful, para peserta akan membayarkan jumlah uang sebagai kontribusi (yang biasa disebut sebagai premium) masing-masing pihak untuk membiayai risiko menggunakan konsep tabbaru' (donasi) dan sebagai bagian terhadap pihak lain (yang disebut dengan perusahaan takaful) dengan perjanjian yang saling menguntungkan. Kafiil berada dibawah tanggung jawab legal untuk menyediakan perlindungan keuangan pada kerugian yang tidak diekspektasikan sepanjang periode yang disepakati. Jika tidak terjadi kerugian pada partisipan sepanjang periode yang spesifik, partisipan akan diberikan hak untuk keseluruhan jumlah premi dibayar bersama dengan pembagian profit dari akumulasi premium berdasarkan prinsip Mudharabah pada teknik keuangan.

Mudharabah dapat dijelaskan sebagai kontrak antara dua belah pihak, penyedia keuangan (partisipan dalam kasus ini) dan entrepreneur (biasa disebut perusahaan takaful) menyediakan kemampuan bisnis ventura. Profit yang dibagikan kepada kedua belah pihak berdasarkan rasio yang telah disepakati. Beberapa perusahaan takaful menggunakan kontrak wakalah. Wakalah adalah kontrak agen antara perusahaan takaful yang berlaku sebagai agen dari peserta melakukan pengelolaan dana takaful. Dibawah beberapa kontrak, perusahaan akan mendapatkan pendapatan. Perencana keuangan Islam juga harus menjelaskan signifikansi perencanaan takaful dalam mengelola risiko kehidupan seseorang

Contoh lainnya adalah dilarangnya penentuan fixed return dan penyaluran kembali dana modal oleh mudharib dalam transaksi mudharabah (pararel mudharabah). Dalam transaksi mudharabah, shahibul maal dan mudharib sepakat dala penetuan nisbah (porsi) bagi hasil atas keuntungan yang dihasilkan dari kegiatan usaha mudharib dan realisasi keuntungan yang bisa diperoleh kedua belah pihak sangat tergantung dari hasil keuntungan yang diperoleh dari kegiatan usaha mudharib. Jika salah satu pihak, misalnya shahibul maal, mensyaratkan bahwa ia harus menerima keuntungan sebesar nilai tertentu dengan berlakunya syarat tersebut, ia berlepas diri dari risiko kerugian yang mungkin dialami oleh mudharib sehingga terjadi ketidakadilan dimana mudharib menjadi sangat dirugikan. 


\section{Jurnal Asy-Syukriyyah}

Begitu pula dengan transaksi parallel-mudharabah dimana mudharib menggunakan dana shohibul maal untuk melakukan transaksi mudharabah dengan orang ketiga. Transaksi jenis ini telah dilarang banyak ulama. Dalam transaksi tersebut muharib pertama tidak melakukan kegiatan usaha apa pun, mudharib kedualah yang bersusah payah melakukan kegiatan usaha untuk menghasilkan keuntungan. Jika mudharib kedua berhasil mendapatkan keuntungan usaha, maka keuntungan usaha tersebut akan dibagi hasilkan kepada mudharib pertama dan kemudian dibagi hasilkan kembali kepada shahibul maal. Jika mudharib kedua menderita kerugian yang berakibat hilangnya modal, maka mudharib pertama mengklaim bahwa dirinya rugi sehingga shahibul maal terpaksa harul merelakan modalnya hilang karena kerugian tersebut. Mudharib pertama menikmati bagian keuntungan namun tidak menanggung kerugian apa pun sehingga kaidah al-kharaj bin dhaman dan al-ghurmu bil ghunmi dilanggar.

Selain kedua kaidah tersebut syariah islam juga mengajarkan kaidah "la darara wa la dirara" kita tidak diperbolehkan untuk melibatkan diri kita dalam suatu kemudharatan yang akan merugikan atau membinasakan diri kita sendiri tanpa adanya usaha untuk meminimalkan kemudharatan tersebut. Bahkan dalam surat al-Baqarah ayat 195 allah berfirman:

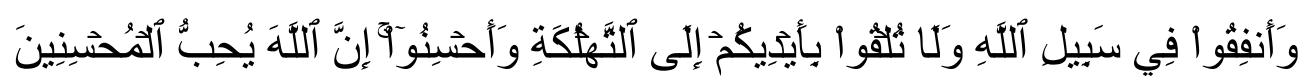

"dan janganlah kamu menjatuhkan dirimu sendiri dalam kebinasaan"

Kaidah ini mendorong bank islam untuk lebih berhati-hati dalam mengelola kegiatan usahanya sehingga setiap risiko yang melekat pada bisnis bank dapat diminimalis dan dikelola dengan baik. Sebelum menyetujui proposal permohonan pembiayaan, bank islam harus mengetahui profil dari debitur tersebut, terutama terkait dengan tingkat resiko yang ada pada debitur tersebut. Dengan mengetahui tingkat resiko yang diperlukan untuk meminimalisasi potensi kerugian dari risiko yang ada.

Ketidak profesionalan bank dalam menyalurkan pinjaman dapat berakibat fatal bagi bank itu sendiri maupun bagi sistem keuangan sacara keseluruhan. Hal ini pernah terjadi pada industri perbankan di indonesia 1997-1998. Krisis perbankan yang terjadi pada periode tersebut dipicu oleh perilaku banyak bank di indonesia yang dengan mudahnya menberikan pinjaman kepada debitur yang tidak layak tanpa memperhitungkan tingkat resiko dan langkah-langkah mitigasi resiko yang dapat dilakukan untuk meminimalisasi 
potensi kerugian yang mungkin terjadi. Boming penyaluran pinjaman tersebut mengakibatkan tingginya nilai kredit macet perbankan pada 1997-1998 sehingga menyebabkan kepercayaan masyarakat terhadap institusi perbankan menurun drastis.

Menurut Rosly Islam mendukung pengambil keputusan untuk berani mengambil risiko karena adanya prinsip al-ghorm bil ghonm dan tidak mendukung risk avoiding behavior. Menurut Rosly keuntungan boleh diakui dalam Islam jika menghasilkan nilai tambah (kasb), dilakukan dengan kerja usaha serta ada unsur risiko (ghorm) yang mesti ditanggung. Meskipun demikian, Islam melarang pengambil keputusan mengambil risiko yang berlebihan yang dinamakan gharar. Dengan demikian, pembiayaan dengan prinsip bagi hasil lebih sesuai dengan prinsip muamalat, karena pemilik modal akan menanggung risiko kerugian jika keuntungan tidak sesuai dengan perkiraan, tetapi tidak sampai ke peringkat gharar. Pembiayaan dengan kontrak jual beli dipandang tidak memenuhi prinsip al-ghorm bil ghonm karena return yang diterima bank bersifat tetap. ${ }^{2}$

Adiwarman berpendapat bahwa salah satu sebab mengapa bunga bank adalah riba karena pemilik modal tidak menanggung risiko atas modal yang diinvestasikan, karena dalam investasi selalu ada risk return relationship. Bunga bank tidak memenuhi prinsip " $n o$ risk no gain". Adanya prinsip ini yang menyebabkan ulama mendukung sistem pembagian keuntungan sebagai kontrak utama menggantikan bunga. ${ }^{3}$

Perspektif Islam dalam pengelolaan risiko suatu organsiasi dapat dikaji dari kisah Yusuf dalam mentakwilkan mimpi sang raja pada masa itu. Kisah mimpi sang raja termaktub dalam al-Qur' an Surat Yusuf 43 sebagai berikut:

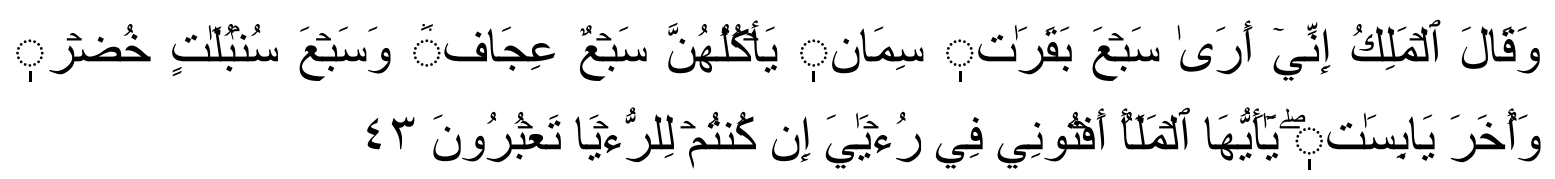

"Sesungguhnya aku bermimpi melihat tujuh ekor sapi betina yang gemuk-gemuk di makan oleh tujuh ekor sapi sapi betina yang kurus-kurus dan tujuh bulir (gandum) yang hijau dan tujuh bulir lainnya yang kering.'Hai orang-orang yang terkemuka: 'Terangkanlah kepadaku tentang ta'bir mimpiku itu jika kamu dapat mena 'birkan mimpi.'(QS. Yusuf: 43).

\footnotetext{
${ }^{2}$ Rosly. (2005). Critical Issue on Islamic Banking and Financial Markets. Dinamas Publishing, Kuala Lumpur, Malaysia.

${ }^{3}$ Adiwarman A. Karim, Bank Islam Analisis fiqh dan keuangan; Jakarta Rajawali Pres 2011
} 


\section{Jurnal Asy-Syukriyyah}

Sedangkan kisah Yusuf mentakwilkan mimpi sang raja dijelaskan dalam alQur'an Surat Yusuf:46-47 sebagai berikut: (Setelah pelayan itu berjumpa dengan Yusuf dia berseru): "Yusuf, hai orang yang amat dipercaya, terangkanlah kepada kami tentang tujuh ekor sapi betina yang gemuk-gemuk yang dimakan oleh tujuh ekor sapi betina yang kurus-kurus dan tujuh bulir (gandum) yang hijau dan (tujuh) lainnya yang kering agar aku kembali kepada orang-orang itu, agar mereka mengetahuinya.Yusuf berkata: "Supaya kamu bertanam tujuh tahun (lamanya) sebagaimana biasa; maka apa yang kamu tuai hendaklah kamu biarkan dibulirnya kecuali sedikit untuk kamu makan.Kemudian sesudah itu akan datang tujuh tahun yang amat sulit, yang menghabiskan apa yang kamu simpan untuk menghadapinya (tahun sulit), kecuali sedikit dari (bibit gandum) yang kamu simpan.Kemudian setelah itu akan datang tahun yang padanya manusia diberi hujan (dengan cukup) dan dimasa itu mereka memeras anggur." (QS. Yusuf: 46-49).

Dalam tafsir Al-Mishbah, M. Quraish Shihab menafsirkan bahwa Nabi Yusuf memahami tujuh ekor sapi sebagai tujuh tahun masa pertanian. Boleh jadi karena sapi digunakan membajak, kegemukan sapi adalah lambang kesuburan, sedang sapi kurus adalah masa sulit dibidang pertanian, yakni masa paceklik. Bulir-bulir gandum lambang pangan yang tersedia. Setiap bulir sama dengan setahun. Demikian juga sebaliknya.

Dari kisah tersebut, bisa dikatakan bahwa pada tujuh tahun kedua akan timbul kekeringan yang dahsyat. Ini merupakan suatu risiko yang menimpa negeri Yusuf tersebut. Namun dengan adanya mimpi sang raja yang kemudian ditakwilkan oleh Yusuf maka kemudian Yusuf telah melakukan pengukuran dan pengendalian atas risiko yang akan terjadi pada tujuh tahun kedua tersebut. Hal ini dilakukan Yusuf dengan cara menyarankan kepada rakyat seluruh negeri untuk menyimpan sebagian hasil panennya pada panenan tujuh tahun pertama demi menghadapi paceklik pada tujuh tahun berikutnya. Dengan demikian maka terhindarlah bahaya kelaparan yang mengancam negeri Yusuf tersebut. Sungguh suatu pengelolaan risiko yang sempurna. Proses manajemen risiko diterapkan Yusuf melalui tahapan pemahaman risiko, evaluasi dan pengukuran, dan pengelolaan risiko. 
Pada dasarnya Allah SWT mengingatkan manusia atau suatu masyarakat, dimana ada kalanya dalam situasi tertentu mempunyai aset dan modal yang kuat, namun suatu saat akan mengalami kesulitan. Hanya saja bagaimana mengatasinya dalam menghadapi kesulitan maka kita harus menyiapkan untuk perhitungan dan pandangan yang luas.

Dalam Hadits juga dikisahkan, salah seorang sahabat Rasulullah Saw. yang meninggalkan untanya tanpa diikatkan pada sesuatu, seperti pohon, tonggak dan lain-lain, lalu ditinggalkan. Beliau s.a.w. bertanya: "Mengapa tidak kamu ikatkan?" Ia menjawab: "Saya sudah bertawakkal kepada Allah." Rasulullah Saw. tidak dapat menyetujui cara berfikir orang itu, lalu bersabda, "Ikatlah dulu lalu bertawakkallah." Ringkasnya tawakkal tanpa usaha lebih dahulu adalah salah dan keliru menurut pandangan Islam. Adapun maksud tawakkal yang diperintahkan oleh agama itu ialah menyerahkan diri kepada Allah sesudah berupaya dan berusaha serta bekerja sebagaimana mestinya. Misalnya meletakkan sepeda di muka rumah, setelah dikunci baik-baik, lalu bertawakkal. Artinya apabila setelah dikunci itu masih juga hilang misalnya dicuri orang, maka dalam pandangan agama orang itu sudah tidak bersalah, sebab telah melakukan ikhtiar supaya jangan sampai hilang. ${ }^{4}$ Makna tawakal ini yang diartikan sebagai manajemen risiko.

Dengan demikian jelaslah, Islam memberi isyarat untuk mengatur posisi risiko dengan sebaik-baiknya, sebagaimana Al-Qur'an dan Hadits mengajarkan kita untuk melakukan aktivitas dengan perhitungan yang sangat matang dalam menghadapi risiko.

\section{Implementasi Four Eyes Principles Bank Syariah}

Aktivitas perkreditan/pembiayaan sampai saat ini merupakan penyumbang terbesar dalam kontribusi laba perbankan, namun aktivitas perkreditan dapat menjadi sumber kerugian Bank karena setiap kredit mengandung resiko yang dapat menyebabkan menurunnya kwalitas kredit dengan meningkatnya Non Performing Loan/Non Performing Financing, sehingga dalam pelaksanannya Bank harus memperhatikan asasasas pemberian kredit yang sehat dan memenuhi prinsip kehati hatian serta adanya independensi para pejabat pelaksanya.

\footnotetext{
${ }^{4}$ Imam An-Nawawi, Riyadhus Shalihin Jilid 1, Penerjemah Achmad Sunarto, (Jakarta: Pustaka Imani, 1999) Cet. IV
} 


\section{Jurnal Asy-Syukriyyah}

Guna mewujudkan visi dan misi Bank dan mengantisipasi kompleksitas resiko kegiatan usaha perbankan, khusunya dalam perkreditan/pembiayaan, maka dipandang perlu untuk melakukan penyempurnaan dalam proses bisnis dan pengambilan keputusan kredit yang dilakukan melalui Four Eyes Principle (FEP).

Secara umum Four Eyes Principle dapat diartikan sebagai fungsi pengendalian (control) dasar pengaturan proses transaksi yang dilakukan melalui sesuatu pemisahan tugas yang jelas dan tegas atas dua pekerjaan yang harus dilakukan oleh dua unit yang berbeda.

Four Eyes Principle merupakan sebuah prinsip dimana setiap keputusan kredit harus melibatkan sinergi antara bisnis unit yang bertanggung jawab dalam pencapaian pendapatan dan unit Resiko Kredit yang bertanggung jawab dalam meminimalisir biaya resiko kredit.

Four Eyes Principle merupakan princip utama yang mendasari pengambilan keputusan dalam pemberian kredit/pembiayaan dimana setiap pemberian kredit minimal dilakukan oleh dua(2) orang pejabat yang masing masing bersal dari unit bisnis dan unit Resiko Kredit yang saling independen satu sama lain.

Four Eyes principle seharusnya berfungsi sebagai pengendalian atau control dasar pengaturan proses transaksi yang dilakukan melalui suatu pemisahan tugas yang jelas dan tegas atau dua pekerjaan yang harus dilakukan oleh dua unit yang berbeda. Implementasi Four Eyes Principle akan meningkatkan kemampuan Relationship Manager (RM) \& Credit Analyst (CA) dalam memahami debitur. Forum rapat kelompok pengusul kredit menjadi ajang bagi para pejabat yang terlibat dalam proses keputusan kredit/pembiayaan untuk menggali pengetahuan, informasi dan pemahaman mengenai debitur.independensi antara unit bisnis dengan unit resiko, akan menghasilkan informasi debitur yang lebih mendalam, transparan dan akurat.

Pemisahan fungsi ini dimaksudkan agar setiap orang dalam jabatannya tidak memeliki peluang untuk melakukan dan/atau menyembunyikan kesalahan atau penyimpangan dalam pelaksanaan tugasnya pada seluruh jenjang organisasi dan seluruh kegiatan operasional. Untuk itu diperlukan penyempurnaan proses pemberian kredit dengan cara menjaga independensi dari masing masing pejabat yang memproses pemberian kredit yang terdiri dari unit bisnis dan unit resiko.(SE No.15/DIR/CRD/2016) Pemisahan fungsi (SE BI No.05/22DPNP tanggal 29 September 2003) 
- Pemisahan fungsi dimaksudkan agar setiap orang dalam jabatannya tidak memiliki peluang untuk melakukan dan menyembunyikan kesalahan atau penyimpangan dalam pelaksanaan tugasnya pada seluruh jenjang organisasi dan seluruh langkah kegiatan operasional,Bank harus mematuhi prinsip pemisahan fungsi ini, yang dikenal sebagai Four Eyes Principle

- Apabila diperlukan,karena perubahan karakteristik kegiatan usaha dan transaksi serta organisasi Bank,Direksi wajib menetapkan prosedur (kewenangan), termasuk penetapan daftar petugas yang dapat mengakses suatu transaksi atau kegiatan usaha yang beresiko tinggi

- Sistem pengendalian intern yang efektif mensyaratkan adanya

- pemisahan fungsi dan menghindari pemberian wewenang dan tanggung jawab yang menimbulkan berbagai benturan kepentingan (Conflict Of Interest).seluruh aspek yg dapat menimbulkan pertentangan kepentingan tersebut harus diidentifikasi,diminimalisir, dan dipantau secara hati hati oleh pihak lain yang independen seperti akuntan public

- Dalam pelaksanaan pemisahan fungsi tersebut bank harus melakukan langkah langkah antara lain:

a) Menetapkan fungsi atau tugas tertentu pada Bank yang harus dipisahkan atau dialokasikan kepada beberapa orang dalam rangka mengurangi resiko terjadinya manipulasi data keuangan atau penyalahgunaan asset Bank.

b) Pemisahan fungsi tersebut tidak terbatas pada kegiatan Front dan Back Office, tetapi juga dalam rangka pengendalian terhadap :1. Persetujuan atas pengeluaran dana dan realisasi pengeluaran,2.Rekening nasabah dan rek pemilik Bank,3.transaksi dalam pembukuan Bank,4.pemberian informasi kepada nasabah bank,5.penilaian terhadap kecukupan dokumentasi perkreditan dan pemantauan debitur setelah pencairan kredit,6.kegiatan usaha lainnya yang dapat menimbulkan benturan kepentingan yang signifikan.7.independensi fungsi manajemen resiko pada bank. 


\section{Jurnal Asy-Syukriyyah}

Implementasi Four Eyes Principle dalam Manajemen Resiko kredit adalah proses Kep utusan Kredit dengan melibatkan Unit Bisnis dan Unit Resiko untuk mengidentifikasi dan membahas semua aspek perkreditan dari suatu aplikasi kredit untuk diusulkan kepada Branch Manager/regional Officer Head kemudian diputus (sesuai dengan limit kewenangan), yang dimaksud dengan Four Eyes Principle (prinsip pelaksanaan empat mata), artinya lebih dari satu orang pelaksana. Jadi four eyes principal itu merupakan fungsi kontrol dasar dengan pengaturan proses transaksi yang dilakukan di perusahaan dilaksanakan minimum oleh 2 orang.

Ada beberapa macam jenis four eyes principle:

a. Dual Control

Suatu aktifitas pemeriksaan yang harus dilakukan untuk memastikan kebenaran dari aktifitas yang telah dilakukan oleh orang sebelumnya. Tujuannya: untuk membatasi resiko yang timbul. Contohnya adalah proses maker checker, user dan supervisor.

b. Dual Custody:

Suatu pekerjaan yang harus dilakukan secara bersama-sama atau di bawah tanggung jawab 2 orang secara bersama-sama. Tujuannya untuk membatasi risiko yang timbul dan penyalahgunaan jika hanya dilakukan oleh 1 orang saja. Contohnya adalah Penanggung Jawab Khasanah Utama, Penanggung jawab uang tunai di khazanah, Cash Delivery/Pick Up, Pemegang kunci dan nomor kombinasi ATM.

c. Segregation of Duty

Suatu pemisahan tugas yang secara jelas dan tegas atas dua pekerjaan yang harus dilakukan oleh dua orang yang berbeda, dimana jika ke-2 pekerjaan tersebut dilakukan oleh orang yang sama maka akan membuka peluang resiko. Jadi tujuannya untuk membatasi risiko yang timbul dan penyalahgunaan jika hanya dilakukan oleh 1 orang saja. Contohnya adalah Penanggung jawab stock/working supply kartu ATM berbeda dengan penanggung jawab PIN Mailer.

Pelaksanaan Four Eyes Principle ini sangat kritikal untuk dijalankan, seringkali dalam kasus terjadi fraud atau pembobolan transaksi dikarenakan pelaksanaan four Eyes Principle ini tidak berjalan sebagaimana mestinya (VIBIZ Conculting membangun proses control (Series of banking operation-2 september 2014))

Mekanisme pengambilan keputusan kredit/pembiayaan komersial dalam penerapan four eyes principle di Kantor Cabang/Kantor Cabang Syariah dan Kantor 
Wilayah (Regional Office) dengan menggunakan konsep MUK-CEO sesuai dengan SE No. 15/DIR/CRD/2016. Proses pengambilan keputusan kredit melalui Kelompok Pengusul Kredit yang terdiri dari pejabat Unit Bisnis dan Unit Credit Risk untuk kemudian diusulkan kepada pemutus Sedangkan untuk Kantor Pusat mekanisme pengambilan keputusan kredit/pembiayaan komersial dengan Four Eyes Principles melalui Kelompok Pemutus Kredit. Anggota Kelompok Pemutus Kredit terdiri Kepala Unit Bisnis dan Kepala Unit Credit Risk. Dalam memutus pemberian kredit harus disepakati oleh seluruh anggota (tidak ada perbedaan pendapat/dissenting opinion).

Kredit/Pembiayaan Komersial yang diproses melalui mekanisme four eyes principle dalam proses keputusan kredit adalah seluruh kredit komersial. Pihak-pihak yang terlibat dalam proses pemberian kredit, adalah :

\section{Kantor Cabang Unit Usaha Syariah}

\section{1) Pengusul Kredit/Pembiayaan :}

Pengusul kredit/pembiayaan adalah Unit Bisnis yang memproses dan mengusulkan kredit dalam bentuk PAK (Perangkat analisa Kredit) bersama-sama dengan Unit Credit Risk yang menyusun PAR ( Perangkat Analisa Resiko). Unit Bisnis sampai dengan Deputy Branch Manager (DBM) Busines yang ada di Kantor Cabang/Kantor Cabang Syariah. Unit Credit Risk sampai dengan Branch Credit Risk Head (BCRH) yang ada di Kantor Cabang.

2) Pemutus Kredit/Pembiayaan :

Pemutus Kredit Kantor Cabang adalah Kepala Cabang (Branch Manager).

\section{Kantor Wilayah (Regional Office)}

1) Pengusul Kredit/Pembiayaan :

Pengusul kredit/pembiayaan adalah Unit Bisnis yang memproses dan mengusulkan kredit dalam bentuk PAK bersama-sama dengan Unit Credit Risk yang menyusun PAR. Unit Bisnis sampai dengan Deputy Regional Manager (DRM) Busines yang ada di Kantor Wilayah. Unit Credit Risk sampai dengan Regional Credit Risk Head (RCRH) yang ada di Kantor Wilayah.

2) Pemutus Kredit/Pembiayaan :

Pemutus Kredit untuk Kantor Wilayah/Regional Office (RO) adalah Kepala Regional Office (RO). 


\section{Kantor Pusat}

1) Pengusul Kredit/Pembiayaan :

Pengusul kredit adalah pejabat kredit yang memproses dan mengusulkan kredit dalam bentuk PAK atau usulan kredit/pembiayaan bersama-sama dengan Credit Risk (CRD) yang menyusun PAR. Unit pengusul sampai dengan Kepala Departemen. Bila keputusan kredit merupakan kewenangan Direksi atau Forum Rapat Direksi maka Kepala Divisi bertindak sebagai pengusul bersama.

2) Pemutus Kredit/Pembiayaan :

Pemutus kredit di tingkat Divisi (Kantor Pusat) adalah kepala dari Unit Bisnis dan Unit Credit Risk (Kepala CRD) dimana masing-masing pejabat memiliki kewenangan memutus kredit sesuai batas wewenang memutus kredit/pembiayaan. Namun bila wewenang memutus merupakan kewenangan Direksi atau Forum Rapat Direksi maka Kepala Divisi terkait bersama-sama Kepala CRD bertindak sebagai pengusul dan keputusan kredit menjadi kewenangan Direksi atau Rapat Direksi sesuai batas wewenang memutus kredit/pembiayaan. Batas Wewenang Memutus Kredit/Pembiayaan pada Kantor Cabang/Kantor Cabang Syariah, Regional dan Kantor Pusat serta Komite Kredit Direksi mengikuti ketentuan BWMK yang berlaku. Batas Wewenang Memutus Kredit/Pembiayaan kepala CRD mengikuti ketentuan BWMK yang berlaku.

a. Kredit Komersial/Commercial Loan, adalah Kredit yang diberikan kepada pemohon kredit yang berbentuk Badan Usaha Berbadan Hukum maupun Badan Usaha t Modal kerja Kontraktor, Kredit Tidak Berbadan Hukum yang pada umumnya digunakan untuk usaha produktif, meliputi Kredit Modal Kerja Konstruksi/Kredit Yasa Griya, Kredit Investasi,Bank Garansi, Small \& Micro Loan dan Kredit lainnya.

b. Small and Micro Loan adalah produk pembiayaan komersil yang diberikan kepada pengusaha baik perorangan maupun badan usaha yang memenuhi kriteria usaha mikro,kecil dan menengah sebagaimana diatur dalam Undang-Undang Republik Indonesia No.20 tahun 2008 tentang usaha Mikro,Kecil dan Menengah .

c. Commercial Lending Division (CMLD) adalah divisi yang mempunyai tugas mengelola Kredit Komersial termasuk progress restrukturisasi kredit komersil kelompok Permorming Loan yang pada umumnya digunakan untuk usaha 
produktif meliputi Kredit Modal Kerja Konstruksi/Kredit Yasa Griya, Kredit Modak kerja ,Kredit Modal Kerja Kontraktor,Kredit Investasi,Bank Garansi dan kredit lainnya.

d. Sharia Division (SHAD) adalah Divisi yang mempunyai tugas mengelola pembiayaan Komersil termasuk proses restrukturisasi pembiayaan komersil kelompok perfourming Loan yang pada umumnya digunakan untuk usaha produktif.

e. Credit Risk Desk (CRD) adalah satuan unit kerja yang melaksanakan fungsi Risk assessment yang independen dan terpisah dari fungsi Unit Bisnis dan turut melakukan pengambilan keputusan kredit berdasarkan Four eyes Principle untuk kredit baru, perubahan fasilitas kredit dan Restrukturisasi kredit komersil kelompok Perfourming loan.

f. Kelompok Pemutus Kredit (ada dikantor pusat) adalah adalah suatu Fourum yang terdiri dan minimal 2 (dua) pejabat kredit dari Commercial Lending Unit dan Credit Risk Unit yang berwenang dan bertanggung jawab untuk merekomendasikan dana tau memutus kredit sesuai kewenangan yang melekat pada jabatannya.

g. Kelompok Pengusul adalah pejabat di Commersial Lending Unit dan Credit Risk Unit yang mengusulkan dan merekomendasikan serta bertanggung jawab terhadap isi dan kelayakan Perangkat Analisa Kredit (PAK) dan direkomendasikan dengan menendatangani dokumen perangkat analisa Kredit(PAK) dan Perangkat Analisa Resiko (PAR) yang diajukan kepada pejabat Pemutus atau di Kelompok Pemutus Kredit.

h. Memo Usulan Kredit (MUK), adalah suatu dokumen yang berisi resume usulan atas hasil collecting dan verifikasi data, hasil analisa yang dibuat oleh Commercial Lending Unit dan Credit Risk Cabang/Regional atas permohonan kredit calon Debitur yang disampaikan kepada Regional Office Head Atau Branch Manager untuk mendapat keputusan sesuai dengan kewenangannya.

i. Perangkat Analisa Resiko (PAR), adalah dokumen yang berisi hasil analisa dan penilaian dari Credit Risk Analyst terhadap calon debitur atas kelayakan kredit yang ditinjau dari berbagai aspek resiko (manajemen,tekhnis/produksi,keuangan,pemasaran,RPC,Agunan dan Industri) . 


\section{Jurnal Asy-Syukriyyah}

j. Perangkat Analisa Kredit (PAK) adalah dokumen yang berisi analisa usulan kredit yang dibuat oleh Credit analyst untuk setiap permohonan fasilitas kredit, baik kredit permohonan baru, tambahan, perpanjangan,perubahan persyaratan maupun review kredit.

k. Batas Wewenang Memutus Kredit (BWMK) adalah besarnya limit yang diberikan oleh Direksi kepada pejabat untuk memutus Kredit.

1. Credit Risk Analyst (CRA) adalah petugas yang melakukan penilaian terhadap resiko kredit berikut mitigasi berdasarkan data dan inFourmasi dari berkas permohonan kredit dan perangkat aplikasi Kredit (PAK) yang dibuat oleh Unit bisnis maupun inFourmasi lainnya.

m. Credit Risk Head adalah pejabat yang mensupervisi Credit Risk Analyst dan yang melakukan penilaian terhadap resiko kredit berikut mitigasi yang menjadi tanggung jawabnya dan merupakan anggota pemutus kredit.

Pihak-pihak yang terlibat dalam proses kredit, mulai dari tahap proyek sampai tahap monitoring dengan peran dan tanggung jawabnya masing masing. Adapun peran dan tanggung jawab dari tiap -tiap unit adalah:

\begin{tabular}{|c|c|}
\hline \multicolumn{2}{|l|}{ Commercial Lending } \\
\hline $\begin{array}{l}\text { * Funding } \\
* \text { Lending (seluruh proses Manajemen } \\
\quad \text { perkreditan) } \\
\text { * Fee Based Income }\end{array}$ & $\begin{array}{l}\text { *Relatinoship Manajemen } \\
\text { *Cross Selling/Value Chain } \\
\text { *Kunjungan bisnis untuk validasi data } \\
\text { *kualitas data\&hasil analisis yang tertuang dalam PAK } \\
\text { *Keputusan kredit } \\
\text { *Pembuatan SP2k }\end{array}$ \\
\hline \multicolumn{2}{|l|}{ Credit Risk } \\
\hline $\begin{array}{l}\text { Fokus terhadap } \\
\text { *Risk Assesment dan mitigasi }\end{array}$ & $\begin{array}{l}\text { *Menilai risiko dan mitigasi } \\
\text { *Mengajukan usulan kredit }\end{array}$ \\
\hline \multicolumn{2}{|l|}{ Loan Administration } \\
\hline Fokus terhadap administrasi kredit & $\begin{array}{l}\text { *Manitenance rekening dan update data jaminan } \\
\text { *Pencairan kredit/pembiayaan(checklist syarat disposisi dan }\end{array}$ \\
\hline
\end{tabular}




\begin{tabular}{|l|l|}
\hline \multicolumn{1}{|l|}{} & eksekusi) \\
& *Pengarsipan file debitur \\
& *Pelaporan(include monitoring dokumen kredit/pembiayaan) \\
& *Administrasi perjanjian kredit,pengikatan jaminan,asuransi \\
& dll \\
\hline Asset Manajemen Unit & *Restrukturisasi kredit (NPL) \\
\hline Fokus terhadap remedial dan Recovery & *Penyelesaian hapus buku (HB) \\
& *Monitoring kredit NPL dan HB \\
\hline
\end{tabular}

\section{Perangkat Analisa Risiko (PAR)}

Dalam melakukan analisa Risiko, Credit Risk menggunakan Perangkat Analisa Risiko (PAR) yang terdiri dari kertas kerja analisa risiko (KKAR) dan kertas kerja rating. Dalam KKAR diulas potensi risiko yang akan muncul serta mitigasinya serta persyaratan-persyaratan kredit yang harus dipenuhi apabila kredit disetujui, sedangkan dalam rating debitur merupakan alat bantu bagi credit risk guna melakukan analisa risiko bagi calon debitur.

Prosedur Analisa Risiko Umum

- Melakukan Analisa Risiko Industri (Industry Risk Rating)

- Menggunakan hasil analisa keuangan.

- Menggunakan Kondisi Bisnis

- Menggunakan analisa penilaian Manajemen

Menentukan angka rating untuk 5 bidang risiko sbb : *)

- Rating Industri

- Kondisi Bisnis

- Penilaian Keuangan

- Manajemen

- Agunan

Menghitung angka rating tertimbang $\rightarrow$ (angka rating $\mathrm{x}$ bobot relatif)

Menjumlahkan keseluruhan angka rating tertimbang

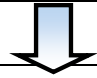

Menentukan Customer Credit Rating dari Debitur 


\section{Jurnal Asy-Syukriyyah}

\begin{tabular}{|l|}
\hline Menentukan Indikasi Risiko \\
\hline Menetapkan Kelayakan Kredit/Pembiayaan
\end{tabular}

*) Keterangan :

Komponen dari masing-masing 4 bidang risiko meliputi :

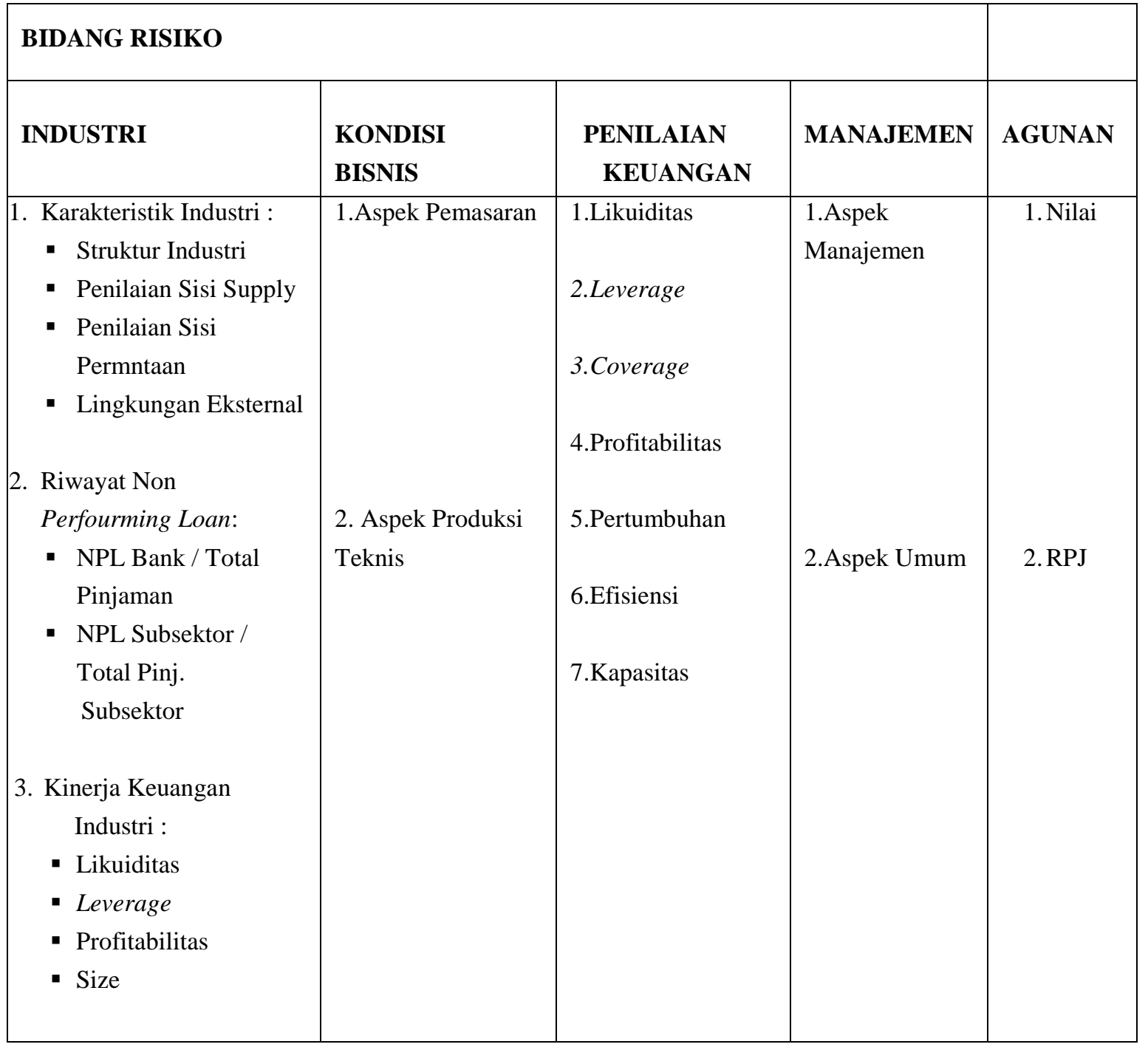


Tingkatan Yudisium

Ada 10 (sepuluh) tingkatan yudisium dalam penilaian risiko kredit, yaitu :
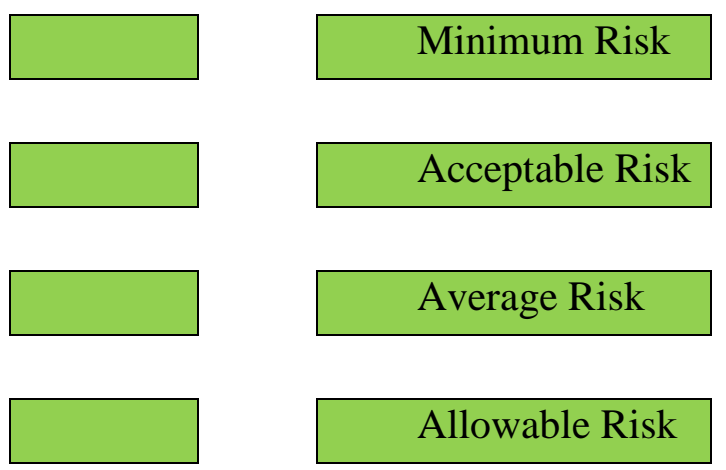

Acceptable Risk

Average Risk

Marginal Risk

NPL
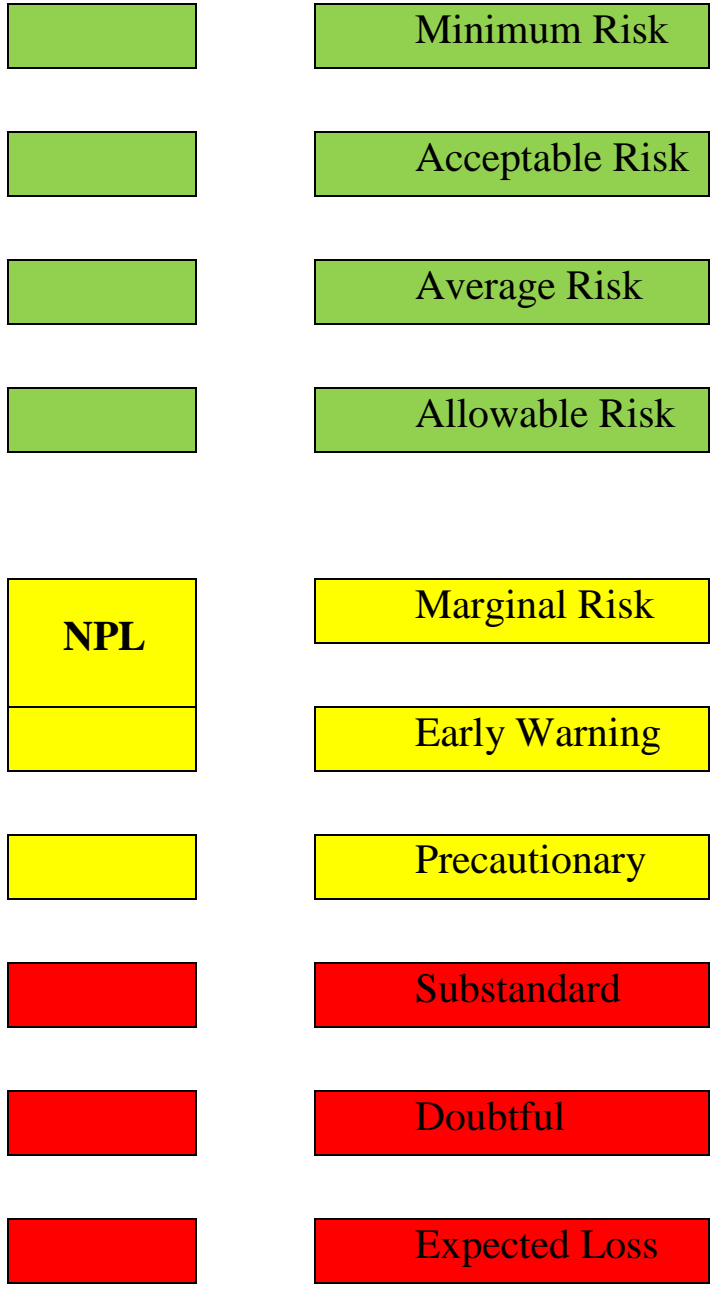

Early Warning

Precautionary

\section{Substandard}

\section{Doubtful}
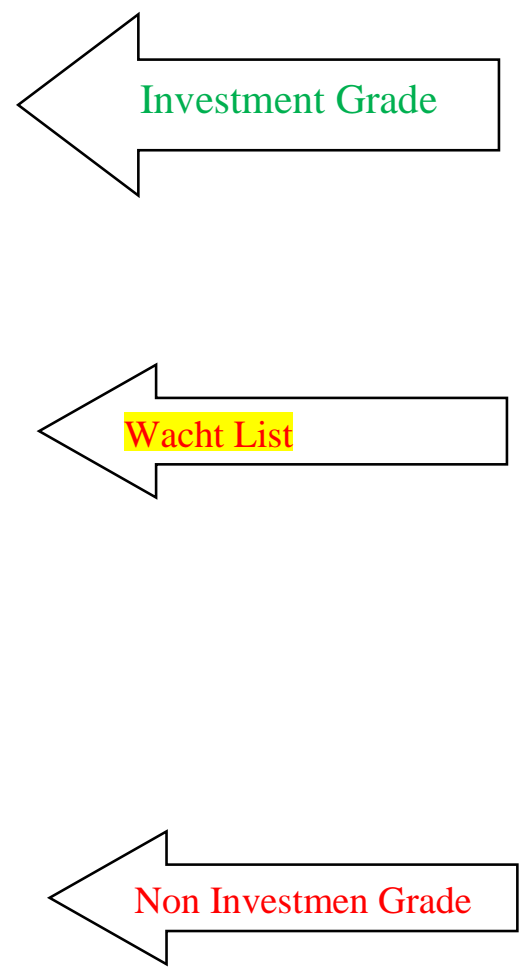

a. Minimum Risk (1), yaitu indikasi bahwa perusahaan berkualitas terbaik layak dan stabil, memiliki kemampuan yang sangat kuat dalam memenuhi kewajiban kepada bank.

b. Acceptable Risk (2), yaitu indikasi bahwa perusahaan berkualitas baik sedikit lebih berisiko dibanding minimum risk.

c. Average Risk (3), yaitu indikasi bahwa perusahaan dalam situasi ekonomi dapat berpengaruh pada kondisi keuangan perusahaan, masih memiliki 


\section{Jurnal Asy-Syukriyyah}

kemampuan dalam memenuhi kewajiban kepada bank, namun sensitive terhadap perubahan kondisi ekonomi.

d. Allowable Risk (4), yaitu indikasi bahwa perusahaan dengan kualitas menengah dimana saat ini dalam kondisi memuaskan memiliki kemampuan yang cukup dalam memenuhi kewajiban kepada bank.

e. Marginal Risk (5), yaitu indikasi bahwa perusahaan ada kecenderungan mengalami perubahan dalam situasi ekonomi, kemampuannya rentan dalam memenuhi kewajibannya.

f. Early Warning (6), yaitu indikasi bahwa perusahaan saat ini goyah tergantung situasi ekonomi yang menguntungkan, kemampuan memenuhi kewajiban sangat rentan.

g. Precautionary (7), yaitu indikasi bahwa perusahaan sangat goyah, sangat spekulatif kemampuan sangat tergantung kondisi bisnis.

h. Substandart (8), yaitu indikasi bahwa perusahaan sangat goyah sekali kemungkinan default / menunggak pembayaran

i. Doubful (9), yaitu indikasi bahwa perusahaan yang akan gagal bayar sebagian atau seluruh kewajibannya (default)

j. $\quad$ Expected Loss (10), yaitu indikasi bahwa perusahaan sudah tidak memiliki kemampuan dan kondisinya sudah macet

Rekomendasi Rating Kredit

a. Apabila Yudicium nasabah masuk dalam kategori Investment Grade (1-4), maka rating memberikan indikasi kredit tersebut dapat direkomendasikan dengan persyaratan sesuai hasil analisa.

b. Apabila Yudicium nasabah masuk dalam kategori Watch List (5-7), maka rating memberikan indikasi kredit tersebut dapat direkomendasikan dengan persyaratan yang sangat ketat

c. Apabila Yudicium nasabah masuk dalam kategori Non Investment Grade (8-10), maka rating memberikan indikasi kredit tersebut tidak dapat direkomendasikan. 


\subsubsection{Prosedur Analisa Risiko Khusus}

Menggunakan hasil analisa dan wawancara dengan debitur

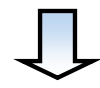

\section{Mengidentifikasi Resiko Khusus}

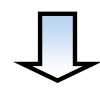

Membahas risiko khusus yang diidentifikasikan tersebut secara jelas

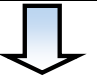

Merekomendasikan Mitigasi Risiko

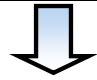

Menolak Permohonan

Apabila berdasarkan analisa risiko umum Pembiayaan masuk dalam rating investmen grade, namun berdasarkan analisa risiko khusus tidak bisa dimitigasi risikonya maka kredit direkomendasikan untuk ditolak.

Kinerja non performing financing BTN Syariah selama 7 tahun terakhir dalam posisi aman NPF hanya 1 persen yang macet, melalui berbagai kebijakan dan yang terbaru dalam pengelolaan pembiayaan yaitu four eyes principles BTN Syariah bisa mempertahankan kinerja lebih baik dalam mengelola kolektibilitas dan merupakan UUS terbaik dalam kinerja.

Tabel 2

Non Performing Financing

\begin{tabular}{|l|l|l|l|l|l|l|l|}
\hline Ketr & 2011 & 2012 & 2013 & 2014 & 2015 & 2016 & 2017 \\
\hline NPF & 3.42 & 2.28 & 1.16 & 2.06 & 1.66 & 1.01 & 0.95 \\
\hline
\end{tabular}

Kesimpulan

- Nabi Yusuf telah melakukan pengukuran dan pengendalian atas risiko yang akan terjadi pada tujuh tahun kedua, hal ini dilakukan Yusuf dengan cara menyarankan kepada rakyat seluruh negeri untuk menyimpan sebagian hasil panennya pada panenan tujuh tahun pertama demi menghadapi paceklik pada tujuh tahun berikutnya. Dengan demikian maka terhindarlah bahaya kelaparan 


\section{Jurnal Asy-Syukriyyah}

yang mengancam negeri Yusuf tersebut. Sungguh suatu pengelolaan risiko yang sempurna, proses manajemen risiko diterapkan Yusuf melalui tahapan pemahaman risiko, evaluasi dan pengukuran, dan pengelolaan risiko.

- Dengan semakin kompleksnya risiko kegiatan usaha perbankan, maka Perbankan Islam (Perbankan Syariah) dituntut untuk menerapkan prinsip kehati-hatian (Prudential Banking) dan Good Coorporate Governance (GCG). Guna mewujudkan visi dan misi dan mengantisipasi kompleksitas risiko kegiatan usaha perbankan, khususnya dalam bidang pembiayaan, maka dipandang perlu untuk melakukan penyempurnaan dalam proses bisnis dan pengambilan keputusan kredit/pembiayaan komersial yang dilakukan melalui Four Eyes Principle (PEF). (SE BI NO. 13/23/DPNP tanggal 25 Oktober 2011 perihal penerapan manajemen Resiko Bagi Bank Umum

- Mekanisme pengambilan keputusan kredit/pembiayaan komersial dalam penerapan four eyes principle di Kantor Cabang/Kantor Cabang Syariah dan Kantor Wilayah (Regional Office) dengan menggunakan konsep MUK-CEO sesuai dengan SE No. 15/DIR/CRD/2016. Proses pengambilan keputusan kredit melalui Kelompok Pengusul Kredit yang terdiri dari pejabat Unit Bisnis dan Unit Credit Risk untuk kemudian diusulkan kepada pemutus Sedangkan untuk Kantor Pusat mekanisme pengambilan keputusan kredit/pembiayaan komersial dengan Four Eyes Principles melalui Kelompok Pemutus Kredit. Anggota Kelompok Pemutus Kredit terdiri Kepala Unit Bisnis dan Kepala Unit Credit Risk. Dalam memutus pemberian kredit harus disepakati oleh seluruh anggota (tidak ada perbedaan pendapat/dissenting opinion). 


\section{DAFTAR PUSTAKA}

Adiwarman A. Karim, Bank Islam Analisis fiqh dan keuangan; Jakarta Rajawali Pres 2011 cetakan ke iv

Departemen Agama Republik Indonesia, Alquran

Otoritas Jasa Keuangan, Sharia Banking Statistic

Bank Indonesia, Surat Edaran Bank Indonesia NO. 13/23/DPNP tanggal 25 Oktober 2011 perihal penerapan manajemen Resiko Bagi Bank Umum

Bank Indonesia, Peraturan Bank Indonesia No.11/25/PBI/2009 tanggal 1 Juli 2009 tentang Perubahan atas Peraturan Bank Indonesia Nomor 5/8/PBI/2003 tentang Penerapan manajemen Risiko Bagi Bank Umum

Bank Indonesia,Peraturan Bank Indonesia No, 13/1/PBI/2011 tanggal 05/10/2011dan SEBI No.13/24/DPNP tanggal 25/10/2011Tentang Penilaian Tingkat kesehatan Bank Umum

Bank Tabungan Negara, Surat Edaran Direksi No. 15/DIR/CRD/2016 tentang Mekanisme pengambilan keputusan kredit/pembiayaan komersial dalam penerapan four eyes principle di Kantor Cabang/Kantor Cabang Syariah dan Kantor Wilayah (Regional Office)

Imam An-Nawawi, Riyadhus Shalihin Jilid 1, Penerjemah Achmad Sunarto, (Jakarta: Pustaka Imani, 1999) Cet. V I

Rosly. Critical Issue on Islamic Banking and Financial Markets. Dinamas Publishing, Kuala Lumpur, Malaysia 2005. 